\title{
A ZENEPEDAGÓGIAI MÓDSZEREK SOKSZÍNÜSÉGE A ZENE ÉS MOZGÁS ÓRÁN
}

\section{DIVERSITY OF MUSIC PEDAGOGY METHODS IN MUSIC CLASSES}

Bartalis Izabella

\begin{abstract}
Musical education, being an integral part of art education, is a field of education, which has an indirect effect on the development of students' inner values, like self-assessment, selfexpression and creativity, resulting in a harmonious well-balanced identity development. In our present study we would like to reflect upon the Romanian Hungarian Music and Movement schoolbook and the quantitative research among school teachers. We woud like to show how different methods meet in the Romanian elementary education system using the Hungarian Kodály conception, being close to our musical mother tongue, and the Orff and Dalcroze methods, which are used in the Romanian educational system. The analysis reflects that most of the elementary school teachers use the Orff-Dalcroze methods and there are ones who do not use any of them.
\end{abstract}

Keywords: Music Education, Music and Movement student's book, absolute solmization, relative solmization

\section{Bevezetés}

A mai modern társadalomban szükséges egy olyan zenepedagógiai koncepció, amely a „ma gyermekét" felkészíti a minőségi zene befogadására. Ehhez szükséges egy jól kidolgozott tanterv és tankönyv, amelyek a tanulók életkori sajátosságainak megfelelően összeállítottak, és amelyek a kompetens zenetanár közvetítésével eljut a tanulókhoz (Kos, 2010). A formális rendszerben történő zenei nevelés a romániai magyar elemi osztályokban a Zene és mozgás tantárgy keretében valósul meg. A 2011-es romániai Tanügyi Törvény értelmében az elemi oktatás előkészítö-1-2. osztályaiban hetente két zene és mozgás óra van, amely 3 - 4. osztályokban, heti egy órára csökken. A 2013/14-ben megjelenő zene és mozgás tanterv újdonságként jelent meg a zenei nevelés terén. Ezt követően a tankönyvkiadás nehezen tudott felzárkózni. Az oktatás minden szegmensében tankönyvhiányt jeleztek, így 2017. szeptember 26-án a minisztérium közzétett egy törvénytervezetet, amely szerint a tankönyvkiadást központosította és kizárólag a Didaktikai és Pedagógiai Kiadó (EDP) foglalkozhatott tankönyvkiadással. A törvény elfogadása után nem a kiadók, hanem közvetlenül a szerzök pályázhattak kézirataikkal. A pályázatok kiírása és leadása között nagyon rövid időintervallum volt megadva, ami a tankönyvek minöségének romlását eredményezte, ez annak is a következménye, hogy az addig a kiadók által felvállalt technikai szerkesztést, illusztrátori, szaklektori, korrektori költségeket nem minden esetben tudták finanszírozni a szerzők.

\section{A kutatásról}

Kutatásunk egyik központi célkitüzése az iskolai ének-zenei nevelés során a tanítók által alkalmazott zenei nevelési módszerek feltérképezése a Kovászna és Hargita megyei magyar tannyelvü elemi osztályaiban. Ennek megfelelően az alábbi kutatási kérdéseinkre kerestük a választ: 1. A tanítók használják-e a rendelkezésre álló Zene és mozgás tankönyveket, és ha igen, akkor melyik zenei 
nevelési irányzatot követö tankönyvet használják? 2. Mi befolyásolja a tanítók tankönyvválasztását? 3. Milyen zenepedagógiai koncepciót, milyen zenepedagógiai módszerek alkalmazását helyezik előtérbe az elemi osztályok tanítói?

A kvantitatív kutatásban résztvevők száma 141, Kovászna és Hargita megye elemi osztályaiban tanító pedagógus, amelynek 98,3\% nő, reprezentálva a tanítói szakma elnőiesedését. Továbbá, a minta alapsokaságában 51,1\%-a Hargita megyében és 48,9\%-a Kovászna megyében tanítanak. A településtípus tekintetében a tanítók 56,4 \% falusi, míg 43,6 \% a városi iskolák elemi osztályos pedagógusai.

Az adatfelvétel 2020. január és 2021. február között került sor. Első lépésként a kutatás folyamatába papíralapú kérdöívet terveztünk, viszont a 2020 tavaszán a COVID-19 következtében megjelenő törvények értelmében tilos volt papíralapú dokumentumokat kézbesíteni. Így kénytelenek voltunk kérdőívünket a virtuális térben, google forms dokumentumként eljuttatni a célcsoporthoz. A kérdőív kiküldését követően, alig néhány nap múlva a pandémiás állapotnak köszönhetően az oktatás áthelyeződött az online térbe, amely annyira leterhelte a tanítókat, hogy többszöri felhívás következtében, egy évvel a kiküldés után is mindössze 141 kitöltött választ kaptunk. Az adatokat statisztikai adatelemző program segítségével dolgoztuk fel, vizsgálva a leíró statisztikai mutatókat.

\section{A Kovászna és Hargita megye magyar elemi osztályaiban alkalmazott zenepedagógiai módszerek}

2018-ban a romániai magyar elemi osztályokban zene és mozgás tantárgyból hat tankönyv jelent meg a 2., 3., és 4. osztályokban, évfolyamonként két-két kiadvány. A kiadványok közül az Ábri Béla Gyergyai Barna - Keresztessy János szerzők által alkotott Zene és mozgás tankönyv jelent meg a 2., 3., és 4. évfolyamok számára, így biztosítva a szerzők által elképzelt koncepció folytonosságát. 2. osztálynak szóló Zene és mozgás könyvet alkotott Molnár Margaréta - Papp Enikő szerzőpáros is. Fórika Éva szerző, pedig a 3. és 4 osztályoknak írt Zene és mozgás tankönyveket. A tankönyveket a bukaresti Didaktikai Kiadó (Editura Didactică S.A.) nyomtatta és ezek pdf formátumban megtekinthetők és virtuálisan lapozhatók a manuale.edu.ro. honlapon is.

1. táblázat. A tankönyvcsaládok által alkalmazott szolmizációs módszer

\begin{tabular}{|c|c|}
\hline Tankönyvcsalád & Az alkalmazott szolmizációs módszer \\
\hline Ábri - Gyergyai - Keresztessy & relatív szolmizáció \\
\hline Fórika Éva & abszolút és relatív szolmizáció \\
\hline Molnár - Papp & abszolút szolmizáció \\
\hline
\end{tabular}

Legfontosabb különbség a tankönyvekben használt zenei olvasás- írás módszerválasztásában van, az Ábri - Gyergyai -Keresztessy szerzők tankönyvcsaládjában a relatív szolmizáció tanítása szerepel, míg a Molnár-Papp 2. osztályos tankönyve a Romániában általánosan használt abszolút szolmizációs módszert alkalmazza. Fórika Éva Zene és mozgás tankönyvei is a zenei írás esetében az abszolút módszert alkalmazza, viszont a kottaolvasás esetében a kottában jelzett kezdőhang jelzéssel a relatív szolmizáció lehetőségét is kínálja.

Abszolút szó jelentése: máshoz nem viszonyított, önálló, korlátlan, teljes, feltétlen. A zenében a diatonikus skála hangjainak egymáshoz való viszonyítását, távolságát jelzi (három egész, egy fél, három egész, egy fél) és a hangokat hangnembeli szerepüktől függetlenül, az Arezzoi Guido-féle szótagokkal (hangnevekkel: dó, re, mi fá, szó lá, ti, dó) jelölő szolmizációs rendszer. Ezzel szemben a Kodály relatív szolmizáció lényege, hogy a hangokat a hangok közötti távolságok függvényében tanítja, vagyis transzponálja a diatonikus skála hangjaira, így bármely hangra helyezhető, tehát egy mozgatható rendszer (Szabó, 2008). 
A romániai zenei nevelés keretében a Nemzeti Tanterv értelmében az abszolút szolmizációs rendszert szükséges tanítani az általános iskola elemi osztályaitól a felsőoktatás szintjéig egyaránt. Viszont a nemzeti identitástudatunknak köszönhetően, a pedagógusok közül néhányan tanítják a relatív szolmizációs rendszert is. Az utóbbi három évben jelent meg a magyar elemi osztályok számára az a Zene és mozgás tankönyv, amely a relatív szolmizációs alapokra építette fel tananyagát.

Elsőként arra voltunk kíváncsiak, hogy a 2018-ban megjelent három tankönyvcsalád közül - amelyek a 2013/2014-ben megjelent zene és mozgás tantervek alapján készültek - a tanítók melyiket használják a zene és mozgás tantárgy tanításánál. A kérdőívben a tankönyvcsaládokat emeltük ki, és azokra kérdeztünk rá így az Ábri-Gyergyai-Keresztessy szerzők a 2.- 4. osztályos tankönyvei, Fórika Éva a 3. és 4. osztályos tankönyveinek használatára kérdeztünk rá konkrétan, míg a Molnár - Papp szerzőpárosok 2. osztályos tankönyve az egyebek kategóriájába sorolható.

2. táblázat. A tanítók által használt tankönyvcsaládok

\begin{tabular}{|c|c|}
\hline \multicolumn{2}{|c|}{ Melyik Zene és mozgás tankönyvet használja osztályával? } \\
\hline Ábri-Gyergyai-Keresztessy & $19,9 \%$ \\
\hline Fórika Éva & $39,7 \%$ \\
\hline nem használok tankönyvet & $28,4 \%$ \\
\hline Egyéb & $7,8 \%$ \\
\hline nem válaszolt & $4,3 \%$ \\
\hline
\end{tabular}

Amint a 2. táblázatban is láthatjuk, a Kovászna és Hargita magyar elemi osztályok 39,7\%- a a Fórika Éva tankönyvcsaládból tanul, míg a tanítók 19,9\% az Ábri,Gyergyai és Keresztessy szerzők Zene és mozgás tankönyveit használ az iskolai zenei nevelés folyamatában. Más, az „egyéb” kategóriába tartozó tankönyvet használnak a tanítók 7,8\%-a. Ide a Molnár és Papp-féle 2. osztályos tankönyvön kívül besorolhatók a tanítók által kedvelt magyarországi tankönyvek, vagy esetleg népdalokat, gyermekdalokat tartalmazó kisebb füzetek is. Amint a 2. sz. táblázatban is látható, az elemi osztályokban tanító pedagógusok 28,4\%-a nem használ tankönyvet a zenei nevelés folyamatában. Annak a lehetősége is fennáll, hogy a zene és mozgás órákat egyéb, általuk fontosnak ítélt tantárgyakból való felzárkóztatásra használják, így egyáltalán nem tartanak zenei foglalkozásokat. A válaszadók 4,3\% nem válaszolt kérdésünkre.

Ebből kiindulva megvizsgáltuk, hogy van-e összefüggés a tanári pályán eltöltött évek és a tankönyvhasználat között. A kérdöív alapján hét csoportba soroltuk a tanári pályán eltöltött évek szerinti a tanítókat, és szignifikáns összefüggést, $(\mathrm{p}=0,003)$ találtunk, a pályán eltöltött évek száma és a zenei írás- olvasás tanításának módszerében. Az eredmények szerint, az Ábri - Gyergyai Keresztessy tankönyvcsaládot a legnagyobb arányban, 39,3\%-ban a 21- 25 év közötti tanítási gyakorlattal rendelkező pedagógusok alkalmazzák. Fórika Éva tankönyveit több generáció is magasabb arányban használja, viszont a legmagasabb százalékban, 30,4\%-ban a 26-30 év tanítói tapasztalattal rendelkezők veszik igénybe. A több mint 30 éves munkaviszonnyal rendelkező pedagógusok 63,6\% -a az „egyéb” kategóriába tartozó tankönyveket alkalmazza a zenetanítás folyamatában. Ez azzal magyarázható, hogy a több, mint 30 éve tanítóként dolgozó pedagógus egy olyan rendszerben kezdte tanítói pályáját, amikor nem voltak ének- zene tankönyvek, így a saját maga által gyüjtött szakkönyvekből volt kénytelen felépíteni a zeneórák anyagait és talán most is azokat alkalmazza. Vizsgálatunk további eredményeként elmondhatjuk, hogy nem használnak tankönyvet a 11-20 és a 26-30 éves tanítói munkaviszonnyal rendelkező pedagógusok 25\%-os arányban, esetükben felmerül az a kérdés is, hogy amennyiben nem használnak tankönyvet, akkor hogyan tanítják meg a zeneelméleti alapokat. 
A könnyebb értelmezhetőség miatt a hét tanítói munkaviszony csoportosítást átkódoltuk négy csoportba: 1. 5 év alatti tanítói régiséggel, 2. 6-10 év közötti tanítói gyakorlattal, 3. 11-25 év tanítói gyakorlattal és 4.26 év fölötti tanítói gyakorlattal rendelkező pedagógusok, így a szignifikancia értéke $\mathrm{p}=0,021$, ami megerősíti, hogy van összefüggés a tanítók tanári pályán töltött évei és a tankönyvhasználat között.

3. táblázat. A tanítók tankönyvhasználata és a tanári pályán eltöltött évek közti összefüggés

\begin{tabular}{|c|c|c|c|c|}
\hline \multirow{2}{*}{$\begin{array}{c}\text { A tanítói pályán } \\
\text { töltött évek száma }\end{array}$} & $\begin{array}{c}\text { Ábri- } \\
\text { Gyergyai- } \\
\text { Keresztessy }\end{array}$ & Fórika Éva & $\begin{array}{c}\text { nem használok } \\
\text { tankönyvet }\end{array}$ & egyéb \\
\hline \multirow{2}{*}{ 5 év alatt } & $22,2 \%$ & $22,2 \%$ & $44,4 \%$ & $11,1 \%$ \\
\hline 6-10 év & $7,7 \%$ & $\underline{\mathbf{8 4 , 6 \%}}$ & $7,7 \%$ & $0,0 \%$ \\
\hline $\mathbf{1 1 - 2 5}$ év & $\underline{\mathbf{2 9 , 1 \%}}$ & $32,7 \%$ & $34,5 \%$ & $3,6 \%$ \\
\hline $\mathbf{2 6}$ év fölött & $15,5 \%$ & $43,1 \%$ & $27,6 \%$ & $\mathbf{1 3 , 6 \%}$ \\
\hline
\end{tabular}

Megjegyzés: Khi-négyzet próba: p= 0,021, , adj. resid >2 (A táblázatban aláhúzással jelöltük azoknak a celláknak az adatait, ahová a véletlenszerü eloszlásnál többen kerültek)

A 3. táblázat alapján választ kaptunk arra, hogy a tanítói tapasztalat, gyakorlat függvényében melyik tankönyvcsaládot használják a tanítók vagy esetlegesen melyik az a csoport, amely egyáltalán nem használ tankönyvet a zene és mozgás órákon. A 11-25 éve tanítóként dolgozók 34,5\%-ban és a fiatal kezdő, 5 év alatt tanári gyakorlattal rendelkezők 44,4\%-ban nem használják egyik tankönyvcsaládot sem a zenei nevelés során. A 6 - 10 éve gyakorló pedagógusként dolgozók 84,6\% -a a Fórika Éva tankönyveket használja a Zene és mozgás órákon. A 11 - 25 év tanítói gyakorlattal rendelkezők 29,1\% az Ábri, Gyergyai és Keresztessy relatív szolmizációs módszeren alapuló tankönyvekből tanítanak a zene és mozgás órákon.

Az Ábri, Gyergyai és Keresztessy tankönyvcsalád szerzői Kovászna megyében, Kézdivásárhelyen, gyakorló zenepedagógusok. Kíváncsiak voltunk, arra is, hogy ez a tény gyakorol-e hatást a Kovászna megyei tanítók tankönyvválasztására, vagyis arra, hogy népszerübb-e ez a tankönyvcsalád Kovászna megyében, mint Hargita megyében? A vizsgálatok alapján találtunk összefüggést a tankönyvcsaládok használata és a tanítók megyénkénti eloszlása között, a szignifikancia értéke p=0,001

4. táblázat. A tanítók tankönyvhasználata és a tanítók megyei eloszlása közti összefüggés

\begin{tabular}{|c|c|c|c|c|}
\hline & \multicolumn{3}{|c|}{ A használt tankönyvek } \\
\cline { 2 - 3 } & $\begin{array}{c}\text { Ábri- } \\
\text { Gyergyai }\end{array}$ & Fórika Éva & $\begin{array}{c}\text { nem használok } \\
\text { tankönyvet }\end{array}$ & egyéb \\
\hline $\begin{array}{c}\text { A tanítók megyei } \\
\text { eloszlása }\end{array}$ & $\begin{array}{c}- \\
\text { Keresztes } \\
\text { sy }\end{array}$ & & \\
\hline
\end{tabular}




\begin{tabular}{|c|c|c|c|c|}
\hline Kovászna megye & $\underline{\mathbf{3 2 , 8 \%}}$ & $40,3 \%$ & $17,9 \%$ & $9 \%$ \\
\hline Hargita megye & $8,8 \%$ & $\underline{\mathbf{4 2 , 6 \%}}$ & $41,2 \%$ & $7,4 \%$ \\
\hline
\end{tabular}

Megjegyzés: Khi-négyzet próba: p= 0,001, adj. resid >3 (A táblázatban aláhúzással jelöltük azoknak a celláknak az adatait, ahová a véletlenszerü eloszlásnál többen kerültek)

Amint a 4. táblázatban is láthatjuk, a feltételezésünk, miszerint az Ábri - Gyergyai - Keresztessy Zene és mozgás tankönyvcsalád nagyobb népszerüségnek örvend Kovászna megyében beigazolódott: 32,8\%-a a Kovászna megyei elemi osztályokban tanítóknak a zene és mozgás óráin, a zenei nevelés folyamatában ebböl a tankönyvcsaládból tanít. Ezzel szemben Hargita megye tanítóinak csak 8,8\%-a választotta osztályának tankönyvként. Tehát elmondhatjuk, hogy a tankönyvszerzők származási helye, ismertsége estünkben befolyással van a tankönyvválasztásra.

A Fórika Éva Zene és mozgás tankönyvcsalád használata mind a két megyében nagyobb arányban van jelen az előző tankönyvcsaládhoz viszonyítva. Kovászna megyében a tanítók 40,3\%-a, Hargita megyében pedig a tanítók 42,6\%-a ezeket a tankönyveket részesíti előnyben a zene és mozgás órák keretében. Fórika Éva neve a romániai magyar zenepedagógia keretében, már a 2000-es évek elejétől ismert, mivel több zenepedagógiai kiadvány füződik nevéhez. Az ének-zene 3. osztályos tankönyv (2001) tanári kézikönyve, majd több ízben az Ének- zene tankönyvek (2005, 2006, 2012) társszerzőjeként is ismertté vált a romániai magyar tanítók körében.

A kérdőívben megjelölt két tankönyvcsalád különböző zenei nevelési irányvonalat, módszert képvisel. Az Ábri - Gyergyai - Keresztessy tankönyvek a Kodály koncepció által használt relatív szolmizációs rendszert használják a zenei írás és olvasás folyamatában, míg a Fórika Éva tankönyvei a zenei olvasás vagyis szolmizáció folyamatában a romániai abszolút és a magyarországi relatív szolmizációnak egyaránt teret ad, viszont a zenei írás esetében csak kimondottan az abszolút rendszert alkalmazza. Ennek tükrében tettük fel kutatási kérdésünket, amelyben arra kerestük a választ, hogy milyen zenepedagógiai koncepciót, milyen zenepedagógiai módszerek alkalmazását helyezik előtérbe az elemi osztályok tanítói. Az adatbázisunk alapjául szolgáló tanítói válaszok alapján a következőket állapítottuk meg.

5. táblázat. A tanítók által használt szolmizációs módszer

\begin{tabular}{|l|c|}
\hline \multicolumn{2}{|c|}{ Melyik módszert alkalmazza a szolmizációs gyakorlatoknál? } \\
\hline abszolút szolmizáció & $44,7 \%$ \\
\hline relatív szolmizáció & $12,8 \%$ \\
\hline abszolút és relatív szolmizációt & $25,5 \%$ \\
\hline egyiket sem & $13,5 \%$ \\
\hline nem válaszolt & $3,5 \%$ \\
\hline
\end{tabular}

Az 5. táblázat szerint a tanítók 44,7\%-a az abszolút szolmizációt alkalmazza a zene és mozgás órákon, 25,5\%-a az abszolút és a relatív szolmizációt egyaránt míg 12,8\%-a csak a relatív szolmizációt használja a zenei képességek fejlesztésében folyamatában. 13,5 \%- a az elemi osztályokban tanítóknak nem tanít, nem alkalmazza egyik szolmizációs módszert sem, így egyértelmüen levonhatjuk azt a következtetést, hogy nem tanítanak zeneelméleti alapokat tanítványaiknak.

Vizsgálatunk következő lépéseként arra kerestük a választ, hogy van-e összefüggés a tanári pályán eltöltött munkaévek és a zenei nevelés során alkalmazott módszerek között. A kérdöívben szereplő, a tanári pályán eltöltött évek szerint hét csoportba sorolt felosztás esetében nem találtunk szignifikáns 
összefüggést a zenei írás - olvasás tanításának módszerében. Ennek következtében a csoportokat átkódoltuk három korcsoportba: 1. 10 év alatti tanítói gyakorlattal, 2. 11-25 év fölötti tanítói gyakorlattal és 3 . 26 év fölötti tanítói gyakorlattal rendelkező pedagógusok, így a szignifikancia értéke $\mathrm{p}=0,016$, ami azt jelzi, hogy van összefüggés a tanítók tanári pályán töltött évek és a tanítók által alkalmazott szolmizációs módszer között.

6. táblázat. A tanítók által alkalmazott szolmizációs módszer és a tanári pályán eltöltött évek közötti összefüggés

\begin{tabular}{|c|c|c|c|c|}
\hline \multirow[b]{2}{*}{$\begin{array}{l}\text { A tanítói pályán } \\
\text { töltöott évek száma }\end{array}$} & \multicolumn{4}{|c|}{ A tanítók által alkalmazott szolmizációs módszer } \\
\hline & $\begin{array}{c}\text { abszolút } \\
\text { szolmozáció }\end{array}$ & $\begin{array}{c}\text { relatív } \\
\text { szolmizáció }\end{array}$ & $\begin{array}{l}\text { abszolút és relatív } \\
\text { szolmizáció }\end{array}$ & egyiket sem \\
\hline 10 év alatt & $26,1 \%$ & $21,7 \%$ & $26,1 \%$ & $26,1 \%$ \\
\hline 11-25 év & $37 \%$ & $13 \%$ & $31,5 \%$ & $18,5 \%$ \\
\hline 26 év fölött & $\underline{62,7 \%}$ & $10,2 \%$ & $22 \%$ & $5,1 \%$ \\
\hline
\end{tabular}

Megjegyzés: Khi-négyzet próba: p= 0,016, adj. resid >3 (A táblázatban aláhúzással jelöltük azoknak a celláknak az adatait, ahová a véletlenszerü eloszlásnál többen kerültek)

A 6. táblázat adatai alapján elmondható, hogy $62,7 \%$ azoknak, akik több, mint 25 éve dolgoznak a tanítói szakmában az abszolút szolmizáció segítségével tanítják a zeneelméleti alapokat. A $11-25$ éves tanítói gyakorlattal rendelkezők $37 \%$ az abszolút és $31,5 \%$ pedig az abszolút és a relatív szolmizációt egyaránt alkalmazza a zene és mozgás órák keretében. A fiatal generációs tanítók esetében majdnem egyenletes megoszlást észlelhetünk, tehát 26,1\%-uk az abszolút, valamint az abszolút és a relatív szolmizációt alkalmazzák a zenei nevelés folyamatában. Feltételezhetően azzal magyarázható, hogy a székelyudvarhelyi tanítóképzésben a realtív és az abszolút szolmizációt egyaránt tanították az 1980 évektől, viszont a tanítók a relatív szolmizációt nehezebben sajátították el. Szintén ebben a csoportban, a kevesebb, mint tíz éve tanítók körében láthatjuk legerőteljesebben, 26,1 \%-ban, hogy egyik szolmizációs módszert sem alkalmazzák, vagyis nem tanítanak zeneelméleti ismereteket tanulóiknak, és csak remélni merjük, hogy ez nem azt jelenti, hogy nem tartják meg a zene és mozgás órákat. Továbbá ennek igazolását vagy az esetleges ellentmondást igazolja a 7. táblázat, amelyben a tanítók életkorát és az alkalmazott szolmizációs módszerek összefüggését vizsgáljuk. A tanítók életkorára vonatkozó kérdésünkben négy korcsoportot jelöltünk meg. Az összefüggést keresve szükséges volt átkódolni két korcsoportba a kutatásban résztvevőket: az első csoportba kerültek a 40 éves vagy annál fiatalabb atnítók, a második csoportba soroltuk a 41 év fölöttieket. A kereszttábla Khi-négyzet értéke p=0, 012.

7. táblázat. A tanítók által alkalmazott szolmizációs módszer és a tanítók életkora közötti összefüggés

\begin{tabular}{|c|c|c|c|c|}
\hline \multirow[b]{2}{*}{ A tanítók életkora } & \multicolumn{4}{|c|}{ A tanítók által alkalmazott szolmizációs módszer } \\
\hline & $\begin{array}{c}\text { abszolút } \\
\text { szolmozáció }\end{array}$ & $\begin{array}{c}\text { relatív } \\
\text { szolmizáció }\end{array}$ & $\begin{array}{l}\text { abszolút és } \\
\text { relatív } \\
\text { szolmizáció }\end{array}$ & egyiket sem \\
\hline $\begin{array}{c}40 \text { év, vagy } \\
\text { fiatalabb }\end{array}$ & $28,6 \%$ & $19 \%$ & $28,6 \%$ & $\underline{23,8 \%}$ \\
\hline
\end{tabular}




\begin{tabular}{|l|l|l|l|l|}
\hline $\mathbf{4 1}$ év fölötti & $\underline{\mathbf{5 4 , 8 \%}}$ & $10,8 \%$ & $25,8 \%$ & $8,6 \%$ \\
\hline
\end{tabular}

Megjegyzés: Khi-négyzet próba: p= 0,012, adj. resid >2,4 (A táblázatban aláhúzással jelöltük azoknak a celláknak az adatait, ahová a véletlenszerü eloszlásnál többen kerültek)

Amint a 7. táblázatban is olvashatjuk, az előzőekhez hasonlóak eredmények, vagyis a 40 évnél fiatalabbak 23,8\% nem használja egyik szolmizációs módszert sem. Szintén ebben a generációban mutatható ki, hogy egyenlő arányban. 28,6\%-ban vannak azok a tanítók, akik az abszolút szolmizációs módszert és azok, akik az abszolút és a relatív módszert egyaránt alkalmazzák a zeneelméleti alapok tanításánál. Vizsgálatunk megerősíti az előző, a munkaviszony időtartamára vonatkozó eredményeket. Az abszolút szolmizációt a 41 év fölötti korosztályba tartozó pedagógusok alkalmazzák a legnagyobb százalékban, 54,8\%-ban, 25,8\%-uk pedig a relatív és az abszolút módszereket egyaránt alkalmazza a zenei írás-olvasás tanításánál, ebben a korcsoportban 8,6\%-ban jelennek meg azok a pedagógusok, akik nem alkalmazzák egyik szolmizációs módszert sem. A 6. és 7. táblázatok eredményei határozottan erősítik egymást.

A tankönyvek használatának tekintetében összefüggést mutatunk ki a tanítók megyei eloszlása és az alkalmazott szolmizációs módszer között. Mivel a tankönyvcsaládok is kategorizálhatók a szolmizációs módszer szerint, feltételeztük, hogy van összefüggés a tanítók megyei szórása és az általuk alkalmazott szolmizációs módszer között. A kereszttábla elemzés során 0,009 szignifikancia mutatható ki.

8. táblázat. A tanítók által alkalmazott szolmizációs módszer és a tanítók megyei eloszlása közötti összefüggés

A tanítók által alkalmazott szolmizációs módszer

\begin{tabular}{|c|c|c|c|c|}
\hline $\begin{array}{c}\text { A tanítók megyei } \\
\text { eloszlása }\end{array}$ & $\begin{array}{c}\text { abszolút } \\
\text { Szolmozáció }\end{array}$ & $\begin{array}{c}\text { relatív } \\
\text { Szolmizáció }\end{array}$ & $\begin{array}{c}\text { abszolút és relatív } \\
\text { szolmizáció }\end{array}$ & egyiket sem \\
\hline Kovászna megye & $\mathbf{3 4 , 8 \%}$ & $12,1 \%$ & $30,3 \%$ & $\underline{\mathbf{2 2 , 7 \%}}$ \\
\hline Hargita megye & $\underline{\mathbf{5 7 , 1 \%}}$ & $14,3 \%$ & $22,9 \%$ & $5,7 \%$ \\
\hline
\end{tabular}

Megjegyzés: Khi-négyzet próba: p= 0,009, , adj. resid >2,6 (A táblázatban aláhúzással jelöltuik azoknak a celláknak az adatait, ahová a véletlenszerü eloszlásnál többen kerültek)

Hargita megye magyar tannyelvü elemi osztályaiban tanító pedagógusok 57,1\%-a, míg Kovászna megyében az elemei tagozaton tanító pedagógusok 34,8\%-a az abszolút szolmizációs módszer segítségével vezeti be a zenei írás - olvasás világába tanítványait. A relatív módszer esetében hasonló eredmény mutatható ki mind a két megyében. Kevés azoknak a tanítóknak a száma, akik kimondottan csak a relatív szolmizációt használják. Magasabb arányban vannak azok, Kovászna megyében 30,3\%, Hargita megyében 22,9\%, akik az abszolút és a relatív szolmizációt egyaránt megismertetik tanulóikkal. A Kovászna megyei tanítók 22,7\% -a egyik módszert sem alkalmazza a zeneelméleti ismeretek tudatosításánál. A fenti feltételezésünk, miszerint párhuzamba állítható a tankönyvcsaládok által használt szolmizációs módszer a zeneelméleti alapok tanításánál alkalmazott módszerrel, nem igazolódott be. Eredményeink alapján láthatjuk, hogy Hargita megyében a tanítók nagyobb arányban $(14,3 \%)$ használják a relatív szolmizációt, ezzel szemben a tankönyvhasználat vizsgálatánál az Ábri - 
Gyergyai - Keresztessy tankönyvek, amelyek a relatív szolmizációra alapoznak Kovászna megyében népszerübbek.

Szignifikáns eredményt találtunk a vidéken, illetve városban tanítók és a szolmizációs módszer alkalmazását illetően. A Khi-négyzet értéke $\mathrm{p}=0,050$.

9. táblázat. A tanítók által alkalmazott szolmizációs módszer és a tanítók munkahelyének település típusa szerinti közötti összefüggés

\begin{tabular}{|c|c|c|c|c|}
\hline \multirow[b]{2}{*}{$\begin{array}{c}\text { A tanítók } \\
\text { munkahelyének } \\
\text { település típusa }\end{array}$} & \multicolumn{4}{|c|}{ A tanítók által alkalmazott szolmizációs módszer } \\
\hline & $\begin{array}{c}\text { abszolút } \\
\text { szolmozáció }\end{array}$ & $\begin{array}{c}\text { relatív } \\
\text { szolmizáció }\end{array}$ & $\begin{array}{l}\text { abszolút és } \\
\text { relatív } \\
\text { szolmizáció }\end{array}$ & egyiket sem \\
\hline vidék & $54,4 \%$ & $7 \%$ & $19,3 \%$ & $19,3 \%$ \\
\hline város & $41 \%$ & $17,9 \%$ & $\mathbf{3 0 , 8 \%}$ & $10,3 \%$ \\
\hline
\end{tabular}

Megjegyzés: Khi-négyzet próba: $\mathrm{p}=0,050$

A vidéken és városban tanítók egyaránt az abszolút szolmizációt használják magasabb arányban. A vidéken tanítók 19,3\% - a nem alkalmazza egyik szolmizációs módszert sem, ez arra enged következtetni, hogy egyik tankönyvböl sem tanítják a dallamismereti anyagokat . A vidéken tanító pedagógusok 7\%-a alkalmazza kimondottan a relatív szolmizációt, a relatív és az abszolút módszerrel 19,3\% tanítja a zeneelméleti ismereteket. Láthatjuk, hogy a városon tanító pedagógusok nagyobb arányban alkalmazzák a relatív és abszolút szolmizációt egyaránt, ez arra enged következtetni, hogy ők erőteljesebb hangsúlyt fektetnek a zeneelméleti ismeretek átadására. Ezt bizonyítja az az eredmény is, amely szerint a vidéken tanítók 19,3\%-uk egyik módszert sem építi be a zene és mozgás óráiba. Ez utóbbi adat azt a kérdést veti fel, hogy vajon ezek a pedagógusok tanítják-e a gyerekeket szolmizálni? Erre a későbbiekben keressük a választ.

\section{Összegzés}

Kutatásunkban arra kerestük a választ, hogy a tanítók alkalmazzák-e a 2018-ban megjelent Zene és Mozgás tankönyveket. Eredményeink alapján elmondhatjuk, hogy a tanítók 67,4\%-a a zene és mozgás órákon a 2013-as tanterv alapján elkészült tankönyvekből tanít, viszont 28,4\%-a az elemi osztályokban tanítóknak nem használ tankönyvet. Amint az 6. táblázatban láthattuk, a 11- 25 éve tanítóként dolgozók 34,5 \%-ban és a fiatal kezdő, 5 év alatt tanári régiséggel rendelkezők 44,4\%-ban egyik tankönyvet sem használják a zene és mozgás órák keretében. Kérdésként merül fel bennünk, hogy amennyiben nem használnak tankönyvet, akkor hogyan, milyen zenei anyagok segítségével tanítják a tantervben is elöírt dallamismereteket, szolmizációt.

Eredményeink rávilágítnak arra, hogy a több, mint 26 éves tanítói tapasztalattal rendelkező tanítók, vagyis azok, akik a 41 év fölötti korcsoportba tartoznak, az abszolút szolmizációs módszerrel tanítják a dallami ismereteket. Feltételezésünk, amely szerint, a Kovászna és Hargita megyei tanítók, a magyar zenei anyanyelvünknek köszönhetően a hozzánk közel álló magyarországi Kodály-koncepciót és a romániai román nyelvü Zene és mozgás Tanterv által előirányozott Dalcroze- és Orff módszerek ötvözését alkalmazzák a zenei nevelés során csak részlegesen igazolódott be. Vizsgálatunk következtetéseként megfogalmazhatjuk, hogy a relatív és az abszolút szolmizációt arányosan minden korosztályban, a tanítói pályán eltöltött évek esetében is egyformán alkalmazzák. A most középkorúnak számító pedagógusok, akik a 40 év fölötti korosztályba tartoznak, a ’90-es években 
végezték tanulmányaikat, többségük a Székelyudvarhelyen (Hargita megye) és Kézdivásárhelyen (Kovászna megye) akkoriban müködő tanítóképzőkben. A székelyudvarhelyi tanítóképzőben a zeneelméleti órák keretében a relatív szolmizációt tanították, viszont a kézdivásárhelyi tanítóképző az abszolút szolmizácós módszert alkalmazta a zenei nevelés folyamatában. A '80 -as években a tanítóképzők tanterveiben hetente kilenc zeneóra (zeneelmélet, zenetörténet, hangszer, kórus), a '90-es években öt zeneóra szerepelt, míg a 2000-es évektől egyre csökkent a zeneelméleti, zenemódszertani órák száma a tanítókat képező intézményekben. Ez magyarázza a kutatási eredményeinkben visszaköszönő eredményeket, hogy a fiatal generációs tanítók 23,8\%-a egyik szolmizációs módszert sem alkalmazza az elemi osztályosok zenei nevelésében. Egy fél évszázad alatt viszont már fokozatosan csökkentették a zenei nevelésre szánt óraszámokat az érvényes kerettervekben, így mára már Romániában csak a humán tagozatos felső középiskolák első két évében van heti egy énekóra, a tanítóképzőkben, míg 1978-ben heti 9 zeneóra volt, ma már csak heti egy. Mindezek ellenére a zenei nevelés igyekszik betölteni a szükös óraszámok keretei között is a teljes értékü szerepét, vagyis a komplex személyiség fejlesztést.

A zenei nevelés, a zene általi nevelés fontosságát, annak teljes személyiségre gyakorolt pozitív hatását hangsúlyozni kell, szükséges megteremteni annak lehetőségét, hogy a megfelelö tantervek és tankönyvek mellett a tanítók elsajátíthassák a zene tanításához szükséges alapismereteket, kompetenciákat és zenemódszertant, hogy a megfelelő felkészültséggel magabiztosan zeneértő, zeneérző és zenebefogadó generációt nevelhessenek. Kodály Zoltán szavaival élve: „A zenei nevelés rendszerében alapvető és döntő láncszem a tanító. Ha a tanító képzett zenész és hivatását szereti, jól megy a munka, a gyermekek szépen énekelnek, szívesen látogatják az orákat, és ami a legfontosabb: ránevelődnek a zene szeretetére.” (Egy kis számadás. Vt. III. 101. vö Ittzés, 2015, 137)

\section{BIrodalomjegyzék}

Ábri B., Gyergyai B., Keresztessy J. (2018): Zene és mozgás tankönyv II. osztály. Editura didactică și pedagogică S. A. Bukarest.

Ábri B., Gyergyai B., Keresztessy J. (2018): Zene és mozgás tankönyv III. osztály. Editura didactică și pedagogică S. A. Bukarest.

Ábri B., Gyergyai B., Keresztessy J. (2018): Zene és mozgás tankönyv IV. osztály.Editura didactică și pedagogică S. A. Bukarest.

Fórika É.(2018): Zene és mozgás tankönyv III. osztály. Editura didactică şi pedagogică S. A. Bukarest.

Fórika É.(2018): Zene és mozgás tankönyv IV. osztály. Editura didactică și pedagogică S. A. Bukarest.

Kiss V. (2010): Müvészeti nevelés, müvészettel nevelés, müvészetterápia. Iskolakultúra 2010/10, p.18-31 http://real.mtak.hu/57898/

Szabó O. (2008): A tested zene. A zene mozgásanalízise és szintézise. DLA értekezés, Liszt Ferenc Zenemüvészeti Egyetem, Budapest https://apps.lfze.hu/netfolder/PublicNet/Doktori\%20dolgozatok Iszabo_orsolya/disszertacio.pdf

Szücs T. (2017): A zenetanulás társadalmi hatásai. In Váradi J., Szücs T. (szerk.) Sokszínü zenepedagógia, Debreceni Egyetemi Kiadó,

Kos R. P. Jr. (2010). Developing Capacity for Change: A Policy Analysis for the Music Education Profession In: Arts Education Policy Review, 111/3, 97-104.

http://dx.doi.org/10.1080/10632911003626903 (2021.03.02.)

\section{Szerző}

Bartalis Izabella, Debreceni Egyetem BTK Humán Tudományok Doktori Iskola, Nevelés és Művelödéstudományi Program, E-mail: izabellabartalis2018@gmail.com 
